\title{
PERBEDAAN POLA PEMBERIAN ASI ANTARA IBU YANG MELAKUKAN DAN TIDAK MELAKUKAN INISIASI MENYUSU DINI (Studi di Wilayah Kerja Puskesmas Margorejo Kabupaten Pati)
}

\author{
Cindy Martha Sari, Yekti Wirawanni*) \\ Program Studi Ilmu Gizi Fakultas Kedokteran Universitas Diponegoro \\ Jl.Dr.Sutomo No.14, Semarang, Telp (024) 8453708, Email : gizifk@ undip.ac.id
}

\begin{abstract}
Background: Early initiation of breastfeeding (EIB) program is one of the methods to decrease infant mortality rate and has been proven to increase exclusive breastfeeding. Delivery helper and formula milk promotion are factors that influence EIB practice. The aim of this study is to know the differences of breastfeeding pattern between mothers who initiate breastfeeding and who don't initiate breastfeeding and to study factors that influence the failure of EIB in terms of delivery helper (midwives) and formula milk promotion.

Method: This study is a descriptive analytic observational study using quantitative and qualitative approaches. Total subjects in quantitative study are 54 mothers who have infant aged 6 years old. Whereas, qualitative study consists of 5 informans. The selection of subjects in quantitative study used total sampling.

Result: The proportion of EIB is 14,81\%. Mothers who initiate breastfeeding give colostrums $100 \%$, pralacteal

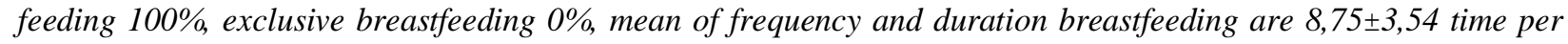
day and 25 22,04 minutes. Mothers who don't initiate breastfeeding give colostrums 89,1\%, pralacteal feeding

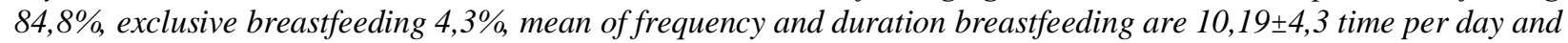
$16,74 \pm 13,1$ minutes.

Conclusion: All mothers who initiate breastfeeding give colostrum and pralacteal feeding but they don't give exclusive breastfeeding. Mothers who don't initiate breastfeeding, don't give colostrums 10,9\%, pralacteal feeding $15,2 \%$ but they give exclusive breastfeeding 4,3\%. However, statistically, there aren't differences of breastfeeding pattern (giving colostrums, pralacteal feeding, exclusive breasfeeding, frequency and duration breastfeeding) between mothers who initiate breastfeeding and who don't initiate breastfeeding.
\end{abstract}

Keywords: breastfeeding pattern; early initiation of breastfeeding

\begin{abstract}
ABSTRAK
Latar Belakang: Program inisiasi menyusu dini (IMD) merupakan salah satu cara menurunkan angka mortalitas bayi dan terbukti meningkatkan keberhasilan ASI eksklusif. Penolong persalinan dan promosi susu formula merupakan faktor yang sangat mempengaruhi pelaksanaan IMD. Penelitian ini bertujuan untuk mengetahui perbedaan pola pemberian ASI antara ibu yang melakukan dan tidak melakukan IMD serta mengkaji faktor yang mempengaruhi kegagalan IMD ditinjau dari faktor penolong persalinan (bidan) dan promosi susu formula.

Metode: Suatu penelitian deskriptif analitik yang bersifat observasional dengan pendekatan kuantitatif dan kualitatif. Jumlah sampel pada penelitian kuantitatif sebanyak 54 ibu yang memiliki bayi berusia 6 bulan, sedangkan penelitian kualitatif terdiri dari 5 informan. Pemilihan subjek penelitian kuantitatif dengan total sampling.

Hasil: Proporsi ibu IMD hanya sebesar 14,81\%. Pada ibu IMD, pemberian kolostrum 100\%, makanan/minuman

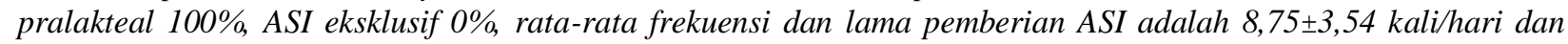
25 22,04 menit. Pada ibu tidak IMD, pemberian kolostrum 89,1\%, makanan/minuman pralakteal 84,8\%, ASI

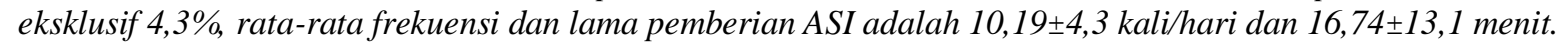

Simpulan: Pola pemberian ASI pada ibu IMD, semuanya memberikan kolostrum, makanan/ minuman pralakteal tetapi tidak memberikan ASI eksklusif. Pola pemberian ASI pada ibu tidak IMD, terdapat 10,9\% ibu tidak memberikan kolostrum, 15,2\% ibu tidak memberikan pralakteal dan 4,3\% ibu memberikan ASI eksklusif. Namun, secara statistik, tidak terdapat perbedaan pola pemberian ASI (pemberian kolostrum, pemberian pralakteal, pemberian ASI eksklusif, frekuensi dan lama pemberian ASI) antara ibu IMD dan tidak IMD
\end{abstract}

Kata Kunci: pola pemberian ASI; inisiasi menyusu dini

${ }^{*}$ Penulis Penanggungjawab 


\section{PENDAHULUAN}

Proporsi kematian bayi yang terjadi pada periode neonatal (1-4 minggu) semakin meningkat tiap tahun (37\% tahun 1990 menjadi 41\% di tahun 2009). ${ }^{1}$ Tiga per empat kematian neonatal terjadi pada minggu pertama dimana merupakan risiko tertinggi kematian pada awal kehidupan. ${ }^{2}$ Sementara itu, hasil data Survei Demografi Kesehatan Indonesia (SDKI, 2007) menyebutkan Angka Kematian Bayi (AKB) sebesar 34 per 1.000 kelahiran hidup. ${ }^{3}$

Berdasarkan tujuan ke-4 MDGs (Millennium Development Goals) menargetkan Indonesia dapat mengurangi AKB menjadi 23 per 1000 kelahiran hidup di tahun 2015. Upaya yang dilakukan pemerintah yakni melalui program inisiasi menyusu dini (IMD) dan dilanjutkan pemberian ASI eksklusif selama 6 bulan. Hal ini telah dibuktikan oleh beberapa studi yang melaporkan bahwa IMD dapat menurunkan AKB. ${ }^{4}$ 6

Inisiasi menyusu dini penting bagi awal kehidupan bayi dan besar manfaatnya untuk bayi maupun ibu. Bayi yang lahir normal dan diletakkan di dada ibu segera setelah lahir dengan kulit ibu melekat pada kulit bayi (skin to skin) selama setidaknya 1 jam, dalam 50 menit akan berhasil menyusu, sedangkan bayi lahir normal yang dipisahkan dari ibunya 50\% tidak bisa menyusu sendiri. ${ }^{7}$ Rangsangan awal terhadap pengeluaran hormon oksitosin sangat mempengaruhi keberhasilan menyusui selanjutnya. ${ }^{8}$ Penelitian Sose et al CIBA Foundation dalam Utami Roesli ${ }^{9}$ menunjukkan bahwa pada usia enam bulan dan satu tahun, bayi yang diberi kesempatan IMD, hasilnya 59\% dan 38\% yang masih disusui. Bayi yang tidak diberi kesempatan IMD tinggal 29\% dan $8 \%$ yang masih disusui di usia yang sama. Berbagai studi juga menyatakan bahwa IMD terbukti meningkatkan keberhasilan ASI eksklusif. ${ }^{7,10-12}$

Meskipun demikian, laporan BPS (2003), menyatakan dari 14.474 anak yang pernah mendapatkan ASI, hanya $38,7 \%$ anak yang mendapat ASI dalam 1 jam pertama. ${ }^{13}$ Sedangkan data Riskesdas (2010) menyebutkan sebesar 29,3\% bayi yang mendapat ASI kurang dari 1 jam pertama setelah persalinan. ${ }^{14}$ Praktek pemberian ASI eksklusif pun cenderung menurun dari $39,5 \%^{13}$ menjadi $34,3 \%{ }^{15}$ dan angka tersebut masih di bawah target pencapaian 80\%. ${ }^{16}$ Disisi lain, jumlah bayi di bawah 6 bulan yang diberi susu formula semakin meningkat dari $16,7 \%{ }^{13}$ menjadi $27,9 \%{ }^{3}$
Sementara itu, secara kuantitatif, praktek IMD di Kabupaten Pati sebesar 61,35\%. ${ }^{17}$ Bahkan, pelaksanaan IMD di Puskesmas Margorejo Kabupaten Pati mencapai 100\%. Akan tetapi, data tersebut tidak didukung dari segi kualitatifnya. Karena berdasarkan hasil survei pendahuluan, beberapa bidan mengatakan belum sepenuhnya menjalankan praktek IMD tergantung pada berbagai faktor/kondisi yang ada. Faktor-faktor yang mempengaruhi kegagalan praktek IMD, diantaranya adalah penolong persalinan (bidan) dan promosi susu formula.

Bidan sebagai salah satu tenaga praktisi dalam pertolongan persalinan mempunyai peranan yang besar dalam keberhasilan praktek IMD. Karena bidan yang terdekat dengan ibu dan pertama yang akan membantu ibu bersalin melakukan IMD. Berdasarkan penelitian Aprilia menyatakan bahwa keberhasilan IMD sangat dipengaruhi oleh sikap dan motivasi bidan. ${ }^{18}$ Kurangnya penerapan praktek IMD dapat disebabkan oleh beberapa faktor bidan, meliputi umur, pendidikan, masa kerja, pengetahuan, dan sikap. ${ }^{19}$

Namun, bidan yang seharusnya memberikan informasi/konsultasi serta mendukung menyusui, telah menjadi media promosi bagi produsen susu formula. ${ }^{20}$ Gencarnya promosi yang dilakukan oleh produsen susu formula dari media massa hingga institusi pelayanan kesehatan seperti Balai Kesehatan Ibu dan Anak (BKIA), telah menggeser perilaku ibu dari pemberian ASI ke penggunaan susu formula. Promosi susu formula tersebut dapat melalui petugas kesehatan maupun non-kesehatan (media massa) sehingga menyebabkan cakupan praktek IMD dan ASI eksklusif mengalami penurunan. ${ }^{21}$ Helen Keller Indonesia (HKI, 2002) ${ }^{22}$ mengungkapkan sebesar $20-53 \%$ bayi telah memperoleh susu formula dari sarana pelayanan kesehatan setelah persalinan.

Sehubungan dengan permasalahan di atas, peneliti tertarik untuk melakukan penelitian tentang perbedaan pola pemberian ASI antara ibu yang melakukan dan tidak melakukan inisiasi menyusu dini.

\section{METODE}

Penelitian ini dilaksanakan pada bulan Maret sampai April 2012 di wilayah kerja Puskesmas Margorejo, Pati. Penelitian ini termasuk dalam lingkup gizi masyarakat dan merupakan jenis penelitian deskriptif-analitik yang bersifat observasional dengan pendekatan kuantitatif dan kualitatif yang digunakan sebagai 
konfirmasi untuk memperkuat data kuantitatif. Penelitian kuantitatif dilakukan untuk mengetahui perbedaan pola pemberian ASI antara ibu IMD dan tidak IMD sedangkan penelitian kualitatif dilakukan untuk mengkaji faktor yang mempengaruhi kegagalan praktek IMD ditinjau dari faktor bidan (pengetahuan, sikap, motivasi bidan) dan promosi susu formula.

Subjek dalam penelitian kuantitafif adalah 54 ibu yang memiliki bayi berusia 6 bulan di wilayah kerja Puskesmas Margorejo Pati. Penelitian kualitatif diambil 5 informan yang terdiri dari 2 orang bidan, ketua pelaksana program KIA dan 2 tenaga kesehatan yang mewakili BKIA di Kecamatan Margorejo Pati, meliputi 1 orang tenaga kesehatan yang bertugas memberikan konseling kepada ibu hamil dan menyusui serta 1 orang tenaga kesehatan yang bertugas merawat bayi baru lahir (BBL).

Pengambilan subjek penelitian kuantitatif berdasarkan teknik total sampling dengan kriteria inklusi yaitu ibu yang memiliki bayi berusia 6 bulan, tidak sedang sakit selama pengambilan data dan dapat diajak berkomunikasi, bersedia menjadi subjek penelitian, bayi tidak mengalami cacat bawaan (bibir sumbing). Pada penelitian kualitatif, kriteria inklusi untuk bidan adalah berstatus bidan yang bekerja di wilayah kerja Puskesmas Margorejo Pati dan bertugas minimal 1 tahun sebagai bidan. Untuk kriteria inklusi tenaga kesehatan di BKIA adalah tenaga kesehatan yang bekerja di BKIA yang bertugas (1) memberikan konseling kepada ibu hamil dan menyusui; (2) merawat bayi baru lahir.

Variabel bebas dalam penelitian kuantitatif adalah praktek IMD, didefinisikan meletakkan bayi segera setelah lahir di dada ibu postpartum setidaknya selama 1 jam sehingga terjadi kontak kulit bayi dengan kulit ibu tanpa alas kain dan bayi memulai menyusu sendiri. Praktek IMD diukur menggunakan 4 skala berdasarkan dua prinsip IMD yaitu kontak kulit bayi dengan kulit ibu (skin to skin) dan bayi belajar menyusu. Skala (1) meletakan bayi segera setelah lahir di dada ibu postpartum, terjadi kontak kulit bayi dengan kulit ibu (tanpa alas kain) dan bayi memulai menyusu sendiri; skala (2) meletakan bayi segera setelah lahir di dada ibu postpartum, terjadi kontak kulit bayi dengan kulit ibu (tanpa alas kain), bayi belum sempat memulai menyusu sendiri; skala (3) bayi lahir, dibersihkan, dibungkus kain/dibedong dan diletakkan di dada ibu untuk disusukan pada ibunya; skala (4) bayi lahir, dibersihkan, dibungkus kain/dibedong, dipisahkan dari ibunya, diberikan makanan/minuman pralakteal, lalu disusukan ke ibunya. Kemudian, keempat skala dikategorikan menjadi dua yaitu IMD (skala 1) dan tidak IMD (skala 2, 3 dan 4). ${ }^{11}$

Variabel terikat berupa pola pemberian ASI yang terdiri dari pemberian kolostrum, pemberian pralakteal, pemberian ASI eksklusif, frekuensi dan lama pemberian ASI. Pemberian kolostrum adalah pemberian ASI yang keluar di hari-hari pertama setelah melahirkan, kental, berwarna kekuning-kuningan. Pemberian pralakteal yaitu bayi mendapat makanan/minuman sebelum ASI keluar, biasanya dilakukan pada hari pertama setelah kelahiran. Pemberian ASI eksklusif adalah bayi yang hanya mendapat ASI saja langsung dari ibunya atau mendapat ASI perahan dan tidak memperoleh makanan cair atau padat lainnya kecuali obat tetes atau sirup yang berisi suplemen vitamin, mineral atau obat sampai usia 6 bulan. ${ }^{23}$ Frekuensi pemberian ASI adalah berapa kali jumlah pemberian ASI dalam satu hari. Lama pemberian ASI adalah durasi pemberian ASI untuk setiap kali menyusui yang diukur dalam satuan menit. Pada penelitian kualitatif, variabel yang diteliti meliputi faktor bidan (pengetahuan, sikap, motivasi) dan promosi susu formula di BKIA. Alat yang digunakan untuk pengambilan data kualitatif adalah pedoman wawancara semi terstruktur dan alat perekam suara.

Selanjutnya, data dianalisis secara statistik menggunakan program Statistical Package for Social Science (SPSS) 17 for Windows. Analisis univariat dilakukan untuk mendeskripsikan data karakteristik subjek penelitian, pola pemberian ASI dan pelaksanaan IMD. Analisis bivariat dilakukan dengan menggunakan uji Chi-Square dan MannWhitney, untuk mengetahui perbedaan pola pemberian ASI antara ibu IMD dan tidak IMD. Analisis data dalam penelitian kualitatif dilakukan sejak pengumpulan data berlangsung, dimana bila jawaban hasil wawancara setelah dilakukan analisis terasa belum memuaskan, maka peneliti melanjutkan pertanyaan lagi, sampai diperoleh data yang kredibel. Data disajikan berdasarkan data yang sudah terkumpul kemudian disimpulkan. ${ }^{24}$

\section{HASIL PENELITIAN \\ Karakteristik Subjek Penelitian}

Diketahui hanya $14,8 \%$ subjek yang melakukan IMD, sedangkan 85,2\% subjek lainnya tidak melakukan IMD. Karakteristik subjek penelitian dilihat berdasarkan umur, pendidikan, pekerjaan, riwayat menyusui antara ibu IMD dan tidak IMD ditunjukkan dalam tabel 1 
Tabel 1. Karakteristik Subjek

\begin{tabular}{|c|c|c|c|c|c|c|}
\hline \multirow{2}{*}{ Karakteristik } & \multicolumn{2}{|c|}{ Ibu IMD $(n=8)$} & \multicolumn{2}{|c|}{$\begin{array}{l}\text { Ibu Tidak IMD } \\
(n=46)\end{array}$} & \multicolumn{2}{|c|}{ Total $(N=54)$} \\
\hline & $\mathbf{n}$ & $\%$ & $\bar{n}$ & $\%$ & $\mathbf{N}$ & $\%$ \\
\hline \multicolumn{7}{|l|}{ Kategori Umur } \\
\hline$<20$ & 0 & 0 & 2 & 4,3 & 2 & 3,7 \\
\hline $20-30$ & 5 & 62,5 & 31 & 67,4 & 36 & 66,7 \\
\hline$>\mathbf{3 0}$ & 3 & 37,5 & 13 & 28,3 & 16 & 29,6 \\
\hline \multicolumn{7}{|l|}{ Pendidikan } \\
\hline SD & 1 & 12,5 & 7 & 15,2 & 8 & 14,8 \\
\hline SMP & 3 & 37,5 & 11 & 23,9 & 14 & 25,9 \\
\hline SMA & 4 & 50 & 24 & 52,2 & 28 & 51,9 \\
\hline Perguruan Tinggi & 0 & 0 & 4 & 8,7 & 4 & 7,4 \\
\hline \multicolumn{7}{|l|}{ Pekerjaan } \\
\hline Tidak bekerja & 5 & 62,5 & 30 & 65,2 & 35 & 64,8 \\
\hline Pegawai Swasta & 1 & 12,5 & 10 & 21,7 & 11 & 20,4 \\
\hline Wiraswasta & 2 & 25 & 6 & 13 & 8 & 14,8 \\
\hline \multicolumn{7}{|l|}{ Riwayat Menyusui } \\
\hline Ada & 6 & 75 & 18 & 39,1 & 24 & 44,4 \\
\hline Tidak ada & 2 & 25 & 28 & 60,9 & 30 & 55,6 \\
\hline \multicolumn{7}{|l|}{ Status Kelahiran } \\
\hline Normal & 8 & 100 & 41 & 89,1 & 49 & 90,7 \\
\hline Operasi caesar & 0 & 0 & 5 & 10,9 & 5 & 9,3 \\
\hline \multicolumn{7}{|l|}{ Penolong Persalinan } \\
\hline Dokter & 0 & 0 & 15 & 32,6 & 15 & 27,8 \\
\hline Bidan & 8 & 100 & 30 & 65,2 & 38 & 70,4 \\
\hline Keluarga & 0 & 0 & 1 & 2,2 & 1 & 1,9 \\
\hline
\end{tabular}

Proporsi usia subyek antara ibu IMD (62,5\%) dan tidak IMD $(67,4 \%)$ kebanyakan berada pada rentang usia 20 hingga 30 tahun. Baik ibu IMD (50\%) maupun tidak IMD $(52,2 \%)$ berpendidikan SMA. Demikian juga dengan pekerjaan, sebagian besar ibu IMD $(62,5 \%)$ dan tidak IMD $(65,2 \%)$ adalah tidak bekerja. Mayoritas ibu IMD (75\%) memiliki riwayat menyusui sebelumnya. Namun, sebanyak $60,9 \%$ ibu tidak IMD, tidak memiliki riwayat menyusui. Baik ibu IMD (100\%) maupun tidak IMD $(89,1 \%)$ melahirkan secara normal. Pada ibu tidak IMD (10,9\%) melahirkan dengan operasi caesar. Bidan lebih mendominasi sebagai penolong persalinan baik dari kelompok IMD $(100 \%)$ maupun tidak IMD $(65,2 \%)$. Sebanyak $32,6 \%$ ibu tidak IMD, persalinannya dibantu oleh dokter.

\section{Praktek Inisiasi Menyusu Dini}

Pelaksanaan IMD dideskripsikan menjadi 4 skala berdasarkan dua prinsip IMD yaitu kontak kulit bayi dengan kulit ibu (skin to skin) dan bayi belajar menyusu. ${ }^{11}$ Deskripsi praktek IMD dapat dilihat pada tabel 2 .

Tabel 2. Deskripsi Praktek Inisiasi Menyusu Dini

\begin{tabular}{|c|c|c|}
\hline Deskripsi IMD & $\bar{n}$ & $\%$ \\
\hline Skala 1 & 8 & 14,8 \\
\hline $\begin{array}{l}\text { Meletakan bayi segera setelah lahir di dada ibu } \\
\text { postpartum, terjadi kontak kulit bayi dengan kulit ibu } \\
\text { (tanpa alas kain) dan bayi memulai menyusu sendiri }\end{array}$ & & \\
\hline Skala 2 & 27 & 50 \\
\hline $\begin{array}{l}\text { Meletakan bayi segera setelah lahir di dada ibu } \\
\text { postpartum, terjadi kontak kulit bayi dengan kulit ibu } \\
\text { (tanpa alas kain), bayi belum sempat memulai } \\
\text { menyusu sendiri }\end{array}$ & & \\
\hline
\end{tabular}




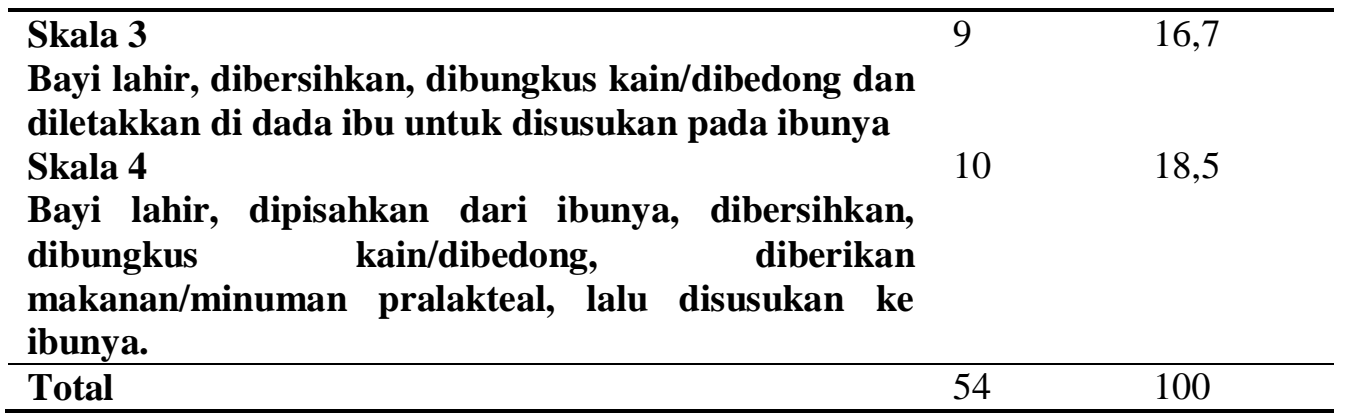

Keempat skala di atas, digolongkan menjadi 2 kategori yaitu kategori IMD untuk skala 1 sebesar $14,8 \%$ dan tidak IMD untuk skala 2, 3 dan 4 sebanyak $85,2 \%$. Sebagian ibu (50\%) melaksanakan IMD sesuai dengan skala 2.

\section{Perbedaan Pola Pemberian ASI antara Ibu} IMD dan Tidak IMD

Perbedaan pemberian kolostrum, makanan/minuman pralakteal, pemberian ASI eksklusif antara ibu IMD dan tidak IMD dapat dilihat pada tabel 3 .

Tabel 3. Distribusi Pemberian Kolostrum, Makanan/Minuman Pralakteal, Pemberian ASI Eksklusif antara Ibu IMD dan Tidak IMD

\begin{tabular}{|c|c|c|c|c|c|c|c|}
\hline \multirow[t]{2}{*}{ Kategori } & \multicolumn{2}{|c|}{ Ibu IMD (n=8) } & \multicolumn{2}{|c|}{$\begin{array}{l}\text { Ibu Tidak IMD } \\
(n=46)\end{array}$} & \multicolumn{2}{|c|}{ Total $(\mathrm{N}=54)$} & \multirow{2}{*}{$\begin{array}{l}\text { Uji } \\
\text { Beda }\end{array}$} \\
\hline & $\mathbf{n}$ & $\%$ & $n$ & $\%$ & $\mathbf{N}$ & $\%$ & \\
\hline $\begin{array}{l}\text { Pemberian } \\
\text { Kolostrum }\end{array}$ & & & & & & & 0,328 \\
\hline Ya & 8 & 100 & 41 & 89,1 & 49 & 90,7 & \\
\hline Tidak & 0 & 0 & 5 & 10,9 & 5 & 9,3 & \\
\hline $\begin{array}{l}\text { Makanan/Minuman } \\
\text { Pralakteal }\end{array}$ & & & & & & & 0,237 \\
\hline $\mathbf{Y a}$ & 8 & 100 & 39 & 84,8 & 47 & 87 & \\
\hline Tidak & 0 & 0 & 7 & 15,2 & 7 & 13 & \\
\hline $\begin{array}{ll}\text { Pemberian } & \text { ASI } \\
\text { Eksklusif } & \end{array}$ & & & & & & & 0,548 \\
\hline Ya & 0 & 0 & 2 & 4,3 & 2 & 3,7 & \\
\hline Tidak & 8 & 100 & 44 & 95,7 & 52 & 96,3 & \\
\hline
\end{tabular}

Tabel.4 Distribusi Jenis Makanan/Minuman Pralakteal

\begin{tabular}{llcccccc}
\hline \multirow{2}{*}{$\begin{array}{c}\text { Kategori Jenis } \\
\text { Makanan/Minuman Pralakteal }\end{array}$} & \multicolumn{2}{c}{$\begin{array}{c}\text { Ibu IMD } \\
(\mathbf{n}=\mathbf{8})\end{array}$} & \multicolumn{2}{c}{$\begin{array}{c}\text { Ibu tidak } \\
\text { IMD }(\mathbf{n = 4 6})\end{array}$} & \multicolumn{2}{c}{ Total (N=54) } \\
\cline { 2 - 8 } & \multicolumn{2}{c}{$\mathbf{n}$} & $\mathbf{\%}$ & $\mathbf{n}$ & $\mathbf{\%}$ & $\mathbf{N}$ & \% \\
\hline Susu Formula & 8 & 100 & 38 & 82,6 & 46 & 85,2 \\
Air Gula & 0 & 0 & 1 & 2,2 & 1 & 1,9 \\
Tidak Pralakteal & 0 & 0 & 7 & 15,2 & 7 & 13 \\
\hline
\end{tabular}

Tabel 3 menunjukkan tidak ada perbedaan antara kedua kelompok dalam memberikan kolostrum kepada bayi ( $\mathrm{p}=0,328)$. Baik ibu IMD $(100 \%)$ maupun tidak IMD $(89,1 \%)$ telah memberikan kolostrum. Namun, masih terdapat $10,9 \%$ ibu tidak IMD yang membuang kolostrum. Demikian juga dengan pemberian pralakteal, tidak terdapat perbedaan antara kedua kelompok dalam pemberian pralakteal $(\mathrm{p}=0,237)$. Kelompok ibu IMD $(100 \%)$ dan tidak IMD $(84,8 \%)$ tetap memberikan pralakteal kepada bayi. Jenis pralakteal dapat dilihat pada tabel 4 dan yang paling banyak diberikan adalah susu formula $(85,2 \%)$. 
Tabel.5 Distribusi Jenis Pengganti ASI (PASI)

\begin{tabular}{lllllllc}
\hline \multirow{2}{*}{ Kategori Jenis PASI } & \multicolumn{2}{c}{$\begin{array}{c}\text { Ibu IMD } \\
(\mathbf{n = 8})\end{array}$} & \multicolumn{2}{c}{$\begin{array}{c}\text { Ibu tidak } \\
\text { IMD }(\mathbf{n = 4 6})\end{array}$} & \multicolumn{2}{c}{ Total (N=54) } \\
\cline { 2 - 8 } & \multicolumn{2}{c}{$\mathbf{n}$} & $\mathbf{\%}$ & $\mathbf{n}$ & $\mathbf{\%}$ & $\mathbf{N}$ & $\boldsymbol{\%}$ \\
\hline Bubur & 2 & 25 & 1 & 2,2 & 3 & 5,6 \\
Bubur, air putih & 0 & 0 & 2 & 4,3 & 2 & 3,7 \\
Susu formula & 4 & 50 & 30 & 65,2 & 34 & 63 \\
Susu formula, bubur & 0 & 0 & 7 & 15,2 & 7 & 13 \\
Tidak PASI & 2 & 25 & 6 & 13 & 8 & 14,8 \\
\hline
\end{tabular}

Ditinjau baik secara statistik maupun deskriptif, tidak terdapat perbedaan pemberian ASI eksklusif antara kedua kelompok $(\mathrm{p}=0,548)$. Semua ibu IMD tidak memberikan ASI eksklusif. Begitu juga dengan ibu tidak IMD, hanya 4,3\% yang memberikan ASI eksklusif (tabel 3). Baik ibu IMD $(100 \%)$ maupun tidak IMD $(65,2 \%)$ memilih susu formula sebagai PASI (tabel 5).

Secara statistik dengan uji Mann-Whitney, tidak terdapat perbedaan frekuensi $(\mathrm{p}=0,324)$ dan lama pemberian ASI $(\mathrm{p}=0,259)$ antara kedua kelompok. Frekuensi pemberian ASI kelompok IMD $(8,75 \pm 3,54 \mathrm{kali} / \mathrm{hari})$ dan tidak IMD $(10,19 \pm 4,3 \mathrm{kali} / \mathrm{hari}) \geq 7 \mathrm{kali} / \mathrm{hari}$. Akan tetapi, berbeda dengan lama pemberian ASI, kelompok ibu IMD $(25 \pm 22,04$ menit) memiliki waktu yang relatif lebih lama dibandingkan dengan ibu tidak $\operatorname{IMD}(16,74 \pm 13,1$ menit$)$.

\section{PEMBAHASAN}

\section{Praktek Inisiasi Menyusu Dini}

Dari hasil penelitian yang diperoleh, ternyata tidak sesuai harapan. Pada kenyataannya, proporsi ibu IMD hanya sebesar 14,8\% (8 subjek), sedangkan $85,2 \%$ lainnya tidak IMD. Proporsi tersebut jauh lebih sedikit dibandingkan proporsi yang didapat dari puskesmas yaitu $100 \%$.

Pada skala 1, praktek IMD sudah mencakup kedua prinsip IMD. Semua ibu IMD (skala 1) masih memberikan pralakteal yang menyebabkan kegagalan ASI eksklusif di hari-hari pertama kelahiran. Namun, dari 8 subjek, diketahui 4 subjek memberikan ASI saja selama 2 bulan, 1 subjek selama 4 bulan, 1 subjek selama 5 bulan, dan 2 subjek selama 6 bulan. Hasil tersebut menunjukkan bahwa IMD tidak menjamin keberhasilan ASI eksklusif. Hal ini berbeda dengan penelitian Fikawati dan Syafiq yang menyatakan ibu IMD kemungkinannya 2-8 kali lebih besar untuk memberikan ASI eksklusif karena ibu IMD kemungkinannya 1,8-5,3 kali lebih besar untuk tidak memberikan pralakteal kepada bayinya. ${ }^{10}$
Sebanyak 50\% praktek IMD dilakukan berdasarkan skala 2. Penolong persalinan hanya membantu meletakan bayi di dada ibu dan membiarkan kontak kulit ibu dengan kulit bayi selama beberapa menit $(6,963 \pm 3,77$ menit $)$, kemudian bayi diambil dan dirawat tanpa kesempatan untuk memulai menyusu sendiri.

Kemudian, skala 3 dan 4 tidak memenuhi kedua prinsip IMD. Namun, skala 3 masih menerapkan rawat gabung, tetapi tidak untuk skala 4. Hal ini disebabkan oleh kondisi bayi/ibu yang buruk, sehingga harus ditangani terlebih dahulu atau bayi langsung dimasukan inkubator untuk diobservasi, biasanya terjadi pada bayi prematur, berat bayi lahir rendah (BBLR), bayi lahir tidak menangis dan asfiksia (skala 3).

Berdasarkan hasil penelitian diketahui persalinan yang dibantu oleh dokter belum sepenuhnya melakukan IMD $(32,6 \%)$. Kemungkinan dikarenakan oleh persalinan di rumah sakit biasanya ditujukan untuk persalinan abnormal seperti caesar, vacuum, forcep atau rujukan dari bidan terkait kondisi ibu/bayi. Ibu yang melahirkan secara caesar, tidak melakukan IMD (10,9\%). Bayi langsung dipisahkan dari ibunya selama beberapa hari untuk dilakukan observasi (skala 4).

\section{Perbedaan Pola Pemberian ASI antara Ibu IMD dan Tidak IMD}

Pola pemberian ASI dalam penelitian kuantitatif meliputi pemberian kolostrum, pemberian pralakteal, pemberian ASI eksklusif, frekuensi dan lama pemberian ASI. Menurut bidan, semua ibu postpartum pasti memberikan kolostrum karena sudah diinformasikan melalui penyuluhan berupa kelas ibu hamil yang diadakan tiap bulan dan saat pemeriksaan antenatal care (ANC). Pada kenyataannya, masih ditemukan $9,7 \%$ ibu tidak IMD yang membuang kolostrum. Alasannya, ASI pertama kotor dan panas bagi bayi karena mbangkaki. Padahal, kolostrum kaya akan antibody yang memberikan perlindungan sistem 
imun dan zat-zat gizi yang tepat untuk tumbuh kembang bayi. ${ }^{25}$ Namun, semua ibu IMD memberikan kolostrum kepada bayinya. Karena bayi yang diberi kesempatan IMD akan lebih dahulu mendapat kolostrum. Sentuhan dan hisapan bayi pada puting susu ibu akan merangsang pengeluaran hormon oksitosin yang berfungsi membantu pengeluaran ASI (let down reflex). ${ }^{9,11}$ Semakin sering bayi menyusu, semakin cepat dan banyak ASI yang keluar. Dari hasil uji bivariat menunjukkan tidak terdapat perbedaan pemberian kolostrum antara kelompok IMD dan tidak IMD $(\mathrm{p}=0,328)$.

Meskipun demikian, baik ibu IMD (100\%) maupun tidak IMD $(84,8 \%)$ tetap memberikan pralakteal dengan alasan ASI belum keluar $(74,5 \%)$. Sebanyak $85,2 \%$ ibu menggunakan susu formula sebagai minuman pralakteal dan sekitar $77,78 \%$ pemberian pralakteal berdasarkan anjuran dari tenaga kesehatan. Hal tersebut sejalan dengan disertasi Februhartanty ${ }^{27}$ yang melaporkan dari $65,3 \%$ bayi yang mendapatkan pralakteal, sebesar $77 \%$ diberikan susu formula dan $80 \%$ atas anjuran tenaga kesehatan. Data hasil penelitian menunjukan bahwa kegagalan ASI eksklusif telah dimulai sejak hari pertama melahirkan yaitu pada saat pralakteal diberikan. ${ }^{10}$ Meskipun ditemukan $15,2 \%$ ibu tidak IMD yang tidak memberikan pralakteal, secara statistik menyebutkan tidak ada perbedaan pemberian pralakteal antara ibu IMD dan tidak IMD ( $\mathrm{p}=0,237)$.

Diketahui semua ibu IMD tidak memberikan ASI eksklusif dengan alasan ibu bekerja, ibu ingin mencobakan makanan kepada bayi, ASI berwarna bening sehingga bayi tidak mau menyusu, bayi lapar dan rewel serta bayi dapat ditinggal berpergian. Meskipun telah diberikan pralakteal, terdapat 2 ibu IMD yang memberikan ASI saja hingga bayi berusia 6 bulan dikarenakan pemberian ASI lebih hemat dan baik bagi pencernaan bayi. Sedangkan pada kelompok ibu tidak IMD, diperoleh 2 ibu yang memberikan ASI secara eksklusif, berstatus tidak bekerja, tidak diberi pralakteal, dan persalinan normal di rumah. Mereka memiliki keinginan yang tinggi untuk memberikan ASI eksklusif sebab ASI lebih baik daripada susu formula dan pertumbuhan bayi. Uji bivariat menunjukkan tidak ada perbedaan pemberian ASI eksklusif antara ibu IMD dan tidak IMD ( $p=0,548)$. Hasil tersebut berbeda dengan penelitian Kramer et al dimana bayi yang diberi kesempatan IMD lebih berhasil disusui secara eksklusif dan lebih lama disusui. ${ }^{28}$
Selain pemberian pralakteal, faktor lain yang menyebabkan kegagalan ASI eksklusif adalah ketidaktahuan ibu untuk memerah/memompa ASI serta pengaruh lingkungan sekitar yang menggunakan susu formula. Hal ini menyebabkan ibu IMD (50\%) maupun tidak IMD $(65,2 \%)$ memilih susu formula sebagai pengganti ASI dengan alasan agar dapat ditinggal berpergian $(31,48 \%)$ dan bayi lapar $(24,07 \%)$. Ibu berpendapat, apabila anak diberikan susu formula sejak dini akan menjadi kebiasaan dan bisa ditinggal berpergian. Padahal, pemberian PASI seperti susu formula menjadi salah satu penyebab ibu tidak memberikan ASI kembali. Pemberian susu formula dengan botol dot dapat menyebabkan bayi bingung puting dan berakibat pada penolakan ASI.

Frekuensi pemberian ASI pada bayi bervariasi tergantung usia bayi. Bayi yang baru lahir dapat menyusu 10-12 kali per hari, sedangkan bayi usia 3-6 bulan hanya menyusu 7-8 kali per hari karena bayi mulai mampu tidur dalam waktu lebih lama. ${ }^{26,29}$ Secara statistik, tidak terdapat perbedaan frekuensi $(p=0,324)$ dan lama pemberian ASI $(\mathrm{p}=0,259)$ antara kedua kelompok. Namun, secara deskriptif, kelompok ibu IMD $(25 \pm 22,04$ menit) memiliki waktu yang relatif lebih lama dalam memberikan ASI daripada ibu tidak IMD (16,74 $\pm 13,1$ menit). Bayi yang diberi ASI, lebih sering lapar dibandingkan dengan bayi yang mendapatkan susu formula karena protein dan lemak pada ASI lebih mudah diserap oleh sistem pencernaan bayi. ${ }^{29}$ Pengenalan PASI sebelum usia 6 bulan dapat mengurangi frekuensi dan lama menyusu sehingga mengganggu proses awal menyusu dan ibu akan memulai pola baru yaitu ketidakcukupan suplai ASI dan dapat menghentikan pemberian ASI. ${ }^{26}$

\section{Faktor yang Mempengaruhi Kegagalan Inisiasi Menyusui Dini}

Studi kualitatif mengkaji faktor yang mempengaruhi kegagalan IMD ditinjau dari faktor bidan sebagai penolong persalinan (pengetahuan, sikap, motivasi bidan) dan promosi susu formula di BKIA.

Bidan merupakan tenaga kesehatan yang paling berperan dalam proses IMD karena ibu tidak dapat melakukan IMD tanpa bantuan dan fasilitasi dari bidan. Berdasarkan hasil interview, pada dasarnya kedua bidan mengetahui deskripsi, tatalaksana dan manfaat IMD. Namun, bidan 1 belum tahu berapa lama proses IMD, sedangkan bidan 2 mampu menjelaskan IMD sesuai teori. 
Dalam prakteknya, bidan 1 menerapkan IMD hanya 5-15 menit saja karena dianggap terlalu lama untuk bayi dapat menyusu. Hal inilah yang menyebabkan kegagalan IMD. Bayi yang sebenarnya dalam keadaan siaga dan siap untuk menyusu, dihambat oleh tindakan bidan karena proses IMD yang lama dan takut bayi kedinginan. Data kuantitatif menunjukkan sebanyak $50 \%$ ibu melakukan IMD sesuai dengan skala 2 (praktek IMD bidan 1). Dan hanya $14,8 \%$ ibu yang melakukan IMD sesuai dengan skala 1 (praktek IMD bidan 2).

Kedua bidan memiliki sikap yang mendukung program IMD, diantaranya senang bila terdapat ibu yang meminta sendiri IMD, menginformasikan IMD melalui kelas ibu hamil dan ANC, mempermudah pekerjaan bidan sebab tidak menggunakan susu formula, serta IMD tercantum dalam Asuhan Persalinan Normal (APN) sehingga sudah menjadi tugas penolong persalinan untuk diterapkan. Akan tetapi, motivasi yang kurang karena malas, menyebabkan bidan tidak menerapkan IMD lagi. Adapula bidan yang berpendapat bahwa bayi lahir harus segera dilakukan asuhan BBL untuk mencegah hipotermia akibat evaporasi air ketuban, perawatan tali pusat dan pemberian profilaksis vitamin $\mathrm{K}$ guna mencegah perdarahan (skala 3). Terkadang bidan juga terburu-buru dikarenakan ada kegiatan lain atau terjadi persalinan di malam hari (bidan mengantuk) sehingga bayi segera diberi asuhan BBL tanpa praktek IMD (skala 3). Disamping itu, praktek IMD tidak dilakukan di setiap persalinan terkait kondisi ibu dan bayi seperti bayi lahir tidak langsung menangis, asfiksia dan persalinan caesar (skala 4). Dari data kuantitatif ditemukan sebesar $16,7 \%$ ibu menerapkan IMD sesuai skala 3 dan $18,5 \%$ ibu sesuai skala 4.

Hal lain yang menghambat praktek IMD adalah ibu merasa ASI tidak keluar. Kedua bidan memberikan susu formula atas permintaan pasien meskipun sebelumnya sudah dijelaskan agar tetap disusui. Berdasarkan data kuantitatif diketahui $85,2 \%$ ibu menggunakan susu formula sebagai minuman pralakteal dan $77,78 \%$ diantaranya atas anjuran tenaga kesehatan. Karena ditemukan beberapa bidan yang menganjurkan atau langsung memberi susu formula tanpa seijin ibu/pihak keluarga terutama dengan alasan ASI belum keluar sehingga sudah menjadi tradisi/kebiasaan dan semakin membudaya.

Pokok permasalahan utama terletak pada pemahaman bidan. Hal ini diungkapkan oleh ketua pelaksana program KIA bahwa pemahaman bidan akan pentingnya pelaksanaan IMD masih kurang, sehingga secara kualitas bidan belum sepenuhnya menerapkan praktek IMD. Bidan juga kurang sabar dalam proses IMD dan terburu-buru memberikan asuhan BBL. Keadaan ini diperburuk dengan belum adanya pelatihan/percontohan praktek IMD, tetapi hanya disosialisasikan secara teori melalui organisasi Ikatan Bidan Indonesia (IBI).

Berawal dari kegagalan IMD, terus berlanjut pada program ASI eksklusif. Kondisi ini menunjukkan sistem birokrasi yang lemah karena belum adanya dukungan/ kerjasama antara bupati dan organisasi IBI dalam bentuk peraturan daerah (Perda) mengenai IMD, ASI eksklusif dan promosi susu formula di Kabupaten Pati. Organisasi IBI hanya memberikan teguran kepada bidan yang melakukan pelanggaran. Pihak puskesmas juga sudah mengadakan pertemuan rutin dimana ketua pelaksana program KIA selalu menegaskan agar bidan tetap melakukan IMD dan mendukung ASI eksklusif serta tidak memberikan susu formula. Namun, peringatan dan teguran yang diberikan belum mampu mencegah pihak-pihak yang melanggar dan sifatnya terbatas pada profesi bidan saja.

Disisi lain, gencarnya promosi yang dilakukan produsen susu formula dari media massa hingga institusi pelayanan kesehatan, telah menggeser perilaku ibu dari pemberian ASI ke penggunaan susu formula. ${ }^{21}$ Balai kesehatan ibu dan anak sebagai salah satu sarana pelayanan kesehatan untuk ibu hamil dan menyusui serta tenaga kesehatan yang seharusnya mendukung kegiatan menyusui, justru menunjukan hal yang sebaliknya. Berdasarkan hasil penelitian di BKIA, terdapat persediaan susu formula yang ditujukan kepada ibu dimana ASI-nya tidak mencukupi dan ibu yang menolak menyusui. Data kuantitatif menyebutkan 85,2\% ibu memberikan susu formula sebagai minuman pralakteal dan $77,78 \%$ diantaranya atas anjuran tenaga kesehatan.

Tenaga kesehatan mendapat informasi susu formula saat kegiatan RTD (Round Table Discuss) yaitu kegiatan dimana tenaga kesehatan memperoleh pengetahuan/informasi kedokteran dan produk. Disamping itu, beberapa tenaga kesehatan pernah mengikuti seminar yang diselenggarakan oleh perusahaan susu formula. Beberapa perusahaan susu formula memang memfasilitasi tenaga kesehatan (bidan) dalam meningkatkan kompetensinya tidak hanya dalam bidang gizi bayi baru lahir tetapi juga kompetensi kebidanan. 
Sebenarnya, BKIA memiliki standar operasional prosedur (SOP) dan kebijakan tertulis mengenai IMD dan ASI eksklusif. Dari hasil wawancara, kedua tenaga kesehatan sudah menerapkan IMD berdasarkan SOP. Selanjutnya, pihak manajemen BKIA juga melakukan konseling kepada ibu hamil dan menyusui tentang IMD dan ASI eksklusif melalui tatap muka/personal dengan media leaflet/poster. Namun, masih ditemukan poster/leaflet kesehatan yang tertera logo/nama produk dan perusahaan susu formula terpampang di ruang konseling. Menurut kedua tenaga kesehatan, media informasi yang diperoleh dari perusahaan susu formula merupakan hal yang baik guna menambah pengetahuan ibu.

Selain itu, setiap ibu bersalin mendapat paket susu formula lengkap dengan tas, produk susu formula, kartu menuju sehat, leaflet yang berisi nama/logo produk dan perusahaan susu formula. Jenis produk susu formula disesuaikan dengan kelas perawatan ibu bersalin. Dari data kuantitatif diketahui mayoritas ibu $(96,3 \%)$ tidak memberikan ASI eksklusif dan $63 \%$ diantaranya memilih susu formula sebagai pengganti ASI.

Berdasarkan uraian diatas diketahui bahwa faktor bidan (pengetahuan, sikap, motivasi) mempengaruhi kegagalan praktek IMD. Meskipun memiliki sikap yang mendukung program IMD, tetapi tidak untuk pengetahuan dan motivasi, menyebabkan kegagalan praktek IMD. Dari faktor promosi susu formula, ditemukan berbagai bentuk promosi yang dilakukan oleh perusahaan susu formula baik kepada tenaga kesehatan maupun BKIA. Hal tersebut turut mendorong ibu untuk mengganti ASI dengan susu formula sehingga kegiatan menyusui menjadi terhambat. Adanya pelanggaran praktek promosi susu formula diduga karena kerjasama mutualisme antara BKIA dan produsen susu formula.

\section{SIMPULAN}

1. Proporsi ibu yang melakukan IMD hanya sebesar 14,8\%, sedangkan ibu tidak IMD sebanyak $85,2 \%$

2. Pola pemberian ASI pada ibu IMD, semuanya memberikan kolostrum, makanan/minuman pralakteal tetapi tidak memberikan ASI eksklusif. Pola pemberian ASI pada ibu tidak IMD, terdapat $10,9 \%$ ibu tidak memberikan kolostrum, 15,2\% ibu tidak memberikan pralakteal dan 4,3\% ibu memberikan ASI eksklusif. Namun, secara statistik tidak terdapat perbedaan pola pemberian ASI (pemberian kolostrum, pemberian pralakteal, pemberian ASI eksklusif, frekuensi dan lama pemberian ASI) antara ibu IMD dan tidak IMD

\section{DAFTAR PUSTAKA}

1. Oestergaard MZ, Mie I, Sachiyo Y, Wahyu RM, Fiona MG, Simon C, et al. Neonatal mortality levels for 193 countries in 2009 with trends since 1990 : a systematic analysis of progress, projections, and priorities. Plos Medicine; 2011.

2. Lawn JE, Simon C, Jelka Z. 4 million neonatal deaths: When? Where? Why? Lancet 2005; 365: 891-900.

3. Badan Pusat Statistik, BKKBN, Departemen Kesehatan. Survei demografi dan kesehatan Indonesia 2006-2007. Jakarta: Badan Pusat Statistik; 2007.

4. Edmond KM, Betty RK, Seeba AE, Seth OA, Lisa SH. Effect of early infant feeding practices on infection-specific neonatal mortality: an investigation of the causal links with observational data from rural ghana. Am J Clin Nutr 2007;86: 1126-31.

5. Edmond KM, Charles Z, Maria AQ, Seeba AE, Seth OA, Betty RK. Delayed breastfeeding initiation increases risk of neonatal mortality. Pediatrics 2006; 117: 380-386.

6. Mullany LC, Joanne K, Yue ML, Subarna KK, Steven CL, Gary LD, et al. Breastfeeding patterns, time to initiation, and mortality risk among newborns in Southern Nepal. J. Nutr. 2008; 138: 599-603.

7. Righard L, Alade MO. Effect of delivery room routines on success of first breast-feed. The Lancet 1990; 336: 1105- 07.

8. Bobak IM, Lowdermilk DL and Jensen MD. Maternity of nursing, fourth edition. Toronto : Mosby year Book Inc; 1995.

9. Roesli U. Inisiasi menyusu dini plus ASI eksklusif. Pustaka Bunda : Jakarta; 2008.

10. Fikawati $\mathrm{S}$ dan Syafiq A. Hubungan antara menyusu segera (immediate breastfeeding) dan pemberian ASI eksklusif sampai dengan empat bulan. Jurnal Kedokteran Trisakti 2003; 22 (2).

11. United Nations Children's Fund (UNICEF) India. Breast crawl : initiation of breastfeeding by breast crawl. New Delhi: UNICEF India; 2007.

12. Vaidya K, Sharma A, Dhungel S. Effect of early mother-baby close contact. Nepal Medical College 7; $2: 138-140 ; 2005$.

13. Badan Pusat Statistik, BKKBN, Departemen Kesehatan. Survei demografi dan kesehatan Indonesia 2002-2003. Jakarta: Badan Pusat Statistik; 2003.

14. Departemen Kesehatan Republik Indonesia. Riset Kesehatan Dasar (Riskesdas) 2010. Jakarta : Depkes RI; 2010.

15. Soepardi J, Ratna R, Hasnawati, Vensya S, Rahmaniar B, Sunaryadi, dkk. Profil Kesehatan 
Indonesia 2009. Jakarta : Kementerian Kesehatan Republik Indonesia; 2010.

16. Departemen Kesehatan Republik Indonesia. Kebijakan dan strategi nasional kesehatan reproduksi di Indonesia. Jakarta : Departemen Kesehatan Republik Indonesia; 2009.

17. Dinas Kesehatan Kabupaten Pati. Data rekapitulasi cakupan inisiasi menyusu dini. Pati : Dinas Kesehatan Kabupaten Pati; 2011.

18. Aprilia Y. Analisis sosialisasi program inisiasi menyusu dini dan ASI eksklusif kepada bidan di kabupten klaten [Tesis]. Semarang : Universitas Diponegoro; 2009.

19. Varida FB. Faktor-faktor pada bidan yang mempengaruhi praktik inisiasi menyusu dini di wilayah kerja dinas kesehatan Kabupaten Pakpak Bharat tahun 2010 [Skripsi]. Semarang : Universitas Diponegoro; 2010.

20. Siswono. Iklan susu formula sudah menyentuh puskesmas [serial on line] 21 Agustus 2010 [cited 15 Mei 2012]. Available from URL : http://gizi.depkes.go.id/.

21. Siswono. Depkes tak mampu awasi promosi PASI sendirian [serial on line] 29 Agustus 2001 [cited 16 Maret 2012]. Available from URL : http://gizi.depkes.go.id/.

22. Hellen Keller Indonesia (HKI). Breastfeeding and complementary feeding practices in Indonesia. Annual report. Jakarta : Hellen Keller Worldwide; 2002.

23. World Health Organization (WHO)/UNICEF/USAID. Indicators for assessing infant and young child feeding practices. Geneva, Switzerland : World Health Organization; 2008.

24. Sugiyono. Metode penelitian kuantitatif kualitatif dan R\&D. Bandung: Alfabeta; 2009.p.243-253.

25. World Health Organization (WHO). Infant and young child feeding : model chapter for textbooks for medical students and allied health professionals. Perancis : WHO; 2009.

26. Wortington-Robert and Bonnie S. Nutrition throughout the life cycle $4^{\text {th }}$ edition. USA : The MicGrawhill Book Companies, Inc; 2000.p.130191.

27. Februhartanty J. Strategic roles of fathers in optimizing breastfeeding practices: a study in an urban setting of Jakarta [dissertation]. Jakarta : Universitas Indonesia; 2008.

28. Kramer MS, Beverley C, Ellen DH, Zinaida S, Irina D, Stanley $\mathrm{S}$, et al. Promotion of breastfeeding intervention trial (PROBIT) : a randomized trial in the Republic of Belarus. JAMA 2001; 285: 4.p.413-420.

29. Perkins S and C Vannais. Breastfeeding for dummies. United States of America : Wiley Publishing, Inc; 2004. 